\title{
THE EFFECT OF BRAND IMAGE AND BRAND TRUST ON CUSTOMER SATISFACTION AND CUSTOMER LOYALTY OF ARA SHOP SIDOARJO
}

\author{
Arum Dwi Dayanti ${ }^{1}$, I Nyoman Sudapet ${ }^{2}$, Hamzah Deny Subagyo ${ }^{3}$ \\ arumdwidayanti@gmail.com, nyomansudapet1@gmail.com, dennysalon@gmail.com \\ Faculty of Economics and Business Management Study Program \\ Narotama University Surabaya
}

\begin{abstract}
The purpose of this study was to analyze the influence of brands image and brand trust on customer satisfaction and customer loyalty in Ara Shop, Sidoarjo. This research is quantitative research. The population and samples were distributed by 60 respondents. Technique of answering data using a questionnaire. Analysis of the data used is Convergence Validity, Discriminant Validity, used and Average Variance Extracted (AVE). Based on the results of the study, the brand image variable and brand trust simultaneously or partially significant towards customer satisfaction and customer loyalty in Ara Shop, Sidoarjo.
\end{abstract}

Keywords: Brand image, brand trust, customer satisfaction, customer loyalty.

\section{INTRODUCTION}

The beauty industry is growing rapidly in Indonesia. this is a variety of trends in society that are beginning to pay attention to skincare as their primary and everyday needs. The lifestyle of women at this time demands to pay more attention to appearance, for that skin care is very important for everyone. Moreover, to overcome various complaints on the skin that can reduce self-confidence. Therefore everyone needs the right product and care. Arashop Sidoarjo is a micro, small and medium business which was established in 2013 founded by Ratih Febrianti. There are 12 kinds of skincare products that are marketed. Arashop Sidoarjo has 87 resellers spread throughout Indonesia. Skincare products are marketed through social media and word of mouth.

Figure 1.1

BPOM statistics
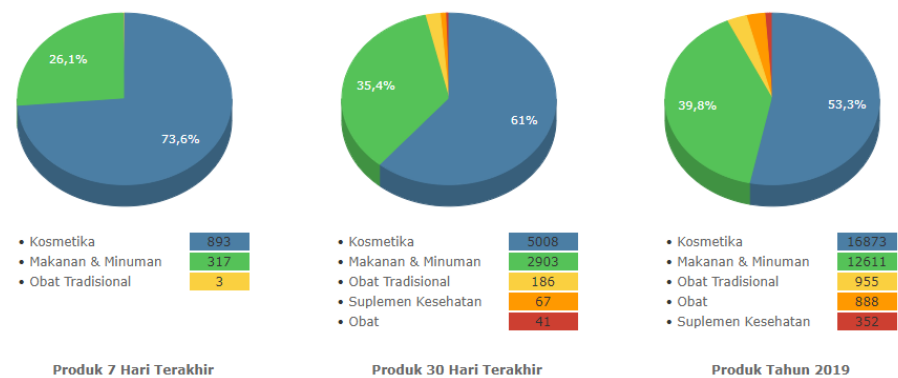

Source: BPOM, 2019

Based on the above data, cosmetic products dominate the products registered in the Food and Drug Supervisory Agency (BPOM). This is a phenomenon that occurs at this time. The number of cosmetic products flooded the market by offering a variety of prices and varied product quality, making competition tighter in the market. So the company must work hard to give the best in order to increase market share. And no less important the company must be able to maintain customer loyalty. So that consumers can be loyal to the product. Without a strong and positive brand image and satisfaction, it is very difficult for companies to attract new customers and retain existing ones. From the description above, this study focuses more on the brand image, and Ara Shop brand trust and for analyzing customer satisfaction and loyalty of customers who have visited and bought in the shop so that researchers raise the topic "The Effect of Brand Image and Brand Trust on Customer Satisfaction and Customer Loyalty in Ara Shop, Sidoarjo"

\section{Brand Image}

Brand Image (X1) According to Kotler (2007: 346) brand image is the perception and belief carried out by consumers, as reflected in the associations that occur in consumer memory 
According to Kotler and Keller (2009), states that brand image indicators include:

1: Strength

2: Uniqueness

3: Passions

\section{Brand Trust}

Brand Trust (X2) According to Lau and Lee (1999) Brand Trust is defined as the desire of customers to rely on a brand with risk risks faced because expectations of the brand will lead to positive results.

According to Kustini (2011: 23), brand trust can be measured through:

1: dimension of viability

2: dimension of intentionality

\section{Customer satisfaction}

Customer Satisfaction (Y1) According to Kotler (2007: 177) satisfaction is the feeling of being happy or disappointed someone who appears after comparing the performance (results) of the product thought about the work (or expected results). If performance is below expectations, customers will not be satisfied. If performance meets expectations, customers will be satisfied. If performance exceeds expectations, customers are very satisfied and happy.

According to Kotler (2007: 275) customers will be satisfied that they will take the following actions:

1: Generally customers will be more loyal for a long time

2: Buy more when the company introduces new products and updates for existing products

3: Talk about good things about the company and its products

4: Less attention to competing brands or advertisements and less price sensitive

5: Offer ideas for services or products to the company

\section{Customer loyalty}

Customer Loyalty (Y2) According to Hurriyati (2008: 129) loyalty is the commitment of customers to re-subscribe or re-purchase selected products / services consistently in the future, even though the influence of the situation and marketing efforts has the potential to cause behavioral changes.

Indicators of customer loyalty according to Zeithaml, Bitner and Dwayne (2009: 47) are:

1: say positive

2: recommend friends, and make a repeat purchase

\section{RESEARCH INTENTION}

\section{Research Approach}

The approach of this research uses a quantitative approach which many research approaches are required to use numbers, starting from data collection, interpretation of the data, as well as the appearance of the results. In this quantitative research there are 4 variables, namely brand image, brand trust, customer satisfaction and customer loyalty.

\section{Population}

The population in the study is the area that researchers want to examine. According to (Sugiyono 2013: 215) the population is a generational region consisting of objects or subjects that have certain qualities and characteristics set by the researcher to be studied and then concluded. The population in this study are consumers or users of products from Ara Shop.

Sample

According to Sugiyono, (2013: 315) the sample is partially or representative of the population studied. This population is for example residents in certain regions, number of employees in a particular organization, number of teachers and students in certain schools and parts.

Based on Joseph F. Hair, (2014), the sample size depends on all the number of indicators multiplied by at least 5 and maximum 10, for the appropriate sample size between 100 to 200. In this study there were 13 indicators, the minimum limit of respondents for this study was $13 \times 5=65$, while the maximum limit is $13 \times 10=$ 130.

\section{Data Analysis Techniques}


In this study the researchers used PLS data analysis techniques using SmartPLS Partial Least Squares (PLS) software which is a powerful analytical method and often referred to as soft modeling because it eliminates the assumption of OLS (Ordinary Least Squares) regression, as data must be normally distributed multivariate and there is no problem of multicoloniality between variables, Wold, 1985 (Ghozali, M.Com, Ph.D, Ak Latan 2015). There are several reasons why in the study used PLS data analysis techniques, namely:

1. The number of samples used does not have to be large (minimum 30)

2. Not assuming certain distributed data, can be nominal, category, ordinal, interval and ratio.

Ghozali (2015) The path analysis model of all latent variables in PLS consists of three sets of relationships, including:

1. Inner model that specifies the relationship between latent variables (structural mode)

2. Outer model that specifies the relationship between latent variables with indicators or manifest variables (measurement mode)

3. Weight relations where assessing cases of latent variables can be estimated. without losing generalization, it can be assumed that latent variables and zero means variable variable manifest indicators and unit variances (standardized values) so that location parameters (constant parameters) can be removed from the model.

\section{RESULT AND DISCUSSION}

\section{Convergent Validity Test}

Table 1. Outer Loading (Measurement Model)

\begin{tabular}{|l|c|c|c|c|}
\hline & X1 & X2 & Y1 & Y2 \\
\hline X1.1 & 0.867 & & & \\
X1.2 & 0.868 & & & \\
X2.1 & 0.840 & & & \\
X2.2 & & 0.855 & & \\
Y1.1 & & 0.945 & & \\
Y1.2 & & & 0.698 & \\
Y1.3 & & & 0.791 & \\
Y1.4 & & & 0.853 & \\
Y2.1 & & & 0.843 & \\
Y2.2 & & & & 0.804 \\
Y2.3 & & & & 0.871 \\
\hline
\end{tabular}

The results of convergent validity tests indicate that the value of the external model or correlation between constructs and latent variables has met convergent validity because the value of loading factors is not below the factor loading limit of 0.50 .

\section{Discriminant Validity Test}

Table 2. Discriminant Validity Value (Cross Loading)

\begin{tabular}{|l|c|c|c|c|}
\hline & $\mathbf{X 1}$ & $\mathbf{X 2}$ & Y1 & Y2 \\
\hline $\mathbf{X 1 . 1}$ & $\mathbf{0 . 8 6 7}$ & 0.174 & 0.603 & 0.666 \\
$\mathbf{X 1 . 2}$ & $\mathbf{0 . 8 6 8}$ & 0.159 & 0.476 & 0.620
\end{tabular}




\begin{tabular}{|l|l|l|l|l|}
$\mathbf{X 1 . 3}$ & $\mathbf{0 . 8 4 0}$ & 0.038 & 0.566 & 0.557 \\
$\mathbf{X 2 . 1}$ & 0.121 & $\mathbf{0 . 8 5 5}$ & -0.123 & 0.101 \\
$\mathbf{X 2 . 2}$ & 0.141 & $\mathbf{0 . 9 4 5}$ & -0.091 & 0.222 \\
$\mathbf{Y 1 . 1}$ & 0.508 & -0.075 & $\mathbf{0 . 6 9 8}$ & 0.555 \\
Y1.2 & 0.437 & -0.099 & $\mathbf{0 . 7 9 1}$ & 0.414 \\
Y1.3 & 0.615 & -0.019 & $\mathbf{0 . 8 5 3}$ & 0.643 \\
Y1.4 & 0.456 & -0.187 & $\mathbf{0 . 8 4 3}$ & 0.523 \\
Y2.1 & 0.529 & 0.088 & 0.590 & $\mathbf{0 . 8 0 4}$ \\
Y2.2 & 0.669 & 0.223 & 0.601 & $\mathbf{0 . 8 7 1}$ \\
Y2.3 & 0.661 & 0.179 & 0.586 & $\mathbf{0 . 9 2 3}$ \\
\hline
\end{tabular}

The results of the discriminant validity test indicate that the value of the loading factor for each indicator of each latent variable has the largest loading factor value if it is associated with a latent variable that has good discriminant validity.

\section{Composite Reliability and AVE Test}

Table 4. Composite Reliability and Averege Variance Extracted

\begin{tabular}{|l|c|c|}
\hline & Composite Reliability & Average Variance Extracted (AVE) \\
\hline X1 & 0.893 & 0.737 \\
X2 & 0.896 & 0.812 \\
Y1 & 0.875 & 0.637 \\
Y2 & 0.901 & 0.753 \\
\hline
\end{tabular}

Composite reliability and AVE test results indicate that all constructions meet reliable criteria. This is indicated by the value of composite reliability above 0.70 and AVE above 0.50 as the recommended criteria.

\section{R Square Test}

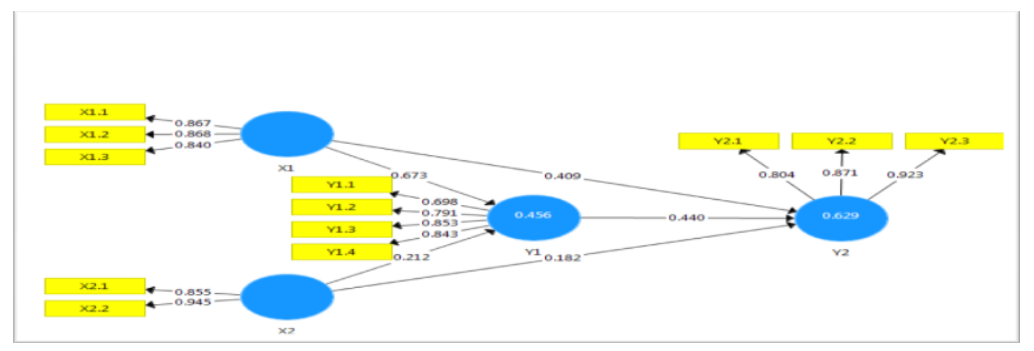

Figure 1. Structural Models

The Square Adjusted R test results show that the Adjusted R Square value for the Customer Satisfaction variable (Y1) is obtained at 0.456 for the Customer Loyalty variable (Y2) obtained at 0.629 . These results indicate that $45.6 \%$ of Customer Satisfaction variables (Y1) can be influenced by Brand Image (X1), and Brand Trust (X2), while Customer Loyalty (Y2) can be influenced by Brand Image (X1) variables, Brand Trust (X2) and Customer Satisfaction (Y1) with a value of $62.9 \%$.

\section{Test Hypothesis}

Table 5. Test Hypothesis 


\begin{tabular}{|c|c|c|c|c|c|}
\hline & $\begin{array}{c}\text { Original } \\
\text { Sample (O) }\end{array}$ & $\begin{array}{c}\text { Sample Mean } \\
(\mathbf{M})\end{array}$ & $\begin{array}{c}\text { Standard } \\
\text { Deviation } \\
\text { (STDEV) }\end{array}$ & $\begin{array}{c}\text { T Statistics } \\
(\text { |O/STDEV|) }\end{array}$ & P Values \\
\hline X1 -> Y1 & 0.673 & 0.692 & 0.093 & 7.229 & 0.000 \\
X1 -> Y2 & 0.409 & 0.427 & 0.181 & 2.261 & 0.012 \\
X2 -> Y1 & -0.212 & -0.200 & 0.108 & 1.963 & 0.025 \\
X2 -> Y2 & 0.182 & 0.173 & 0.085 & 2.133 & 0.017 \\
Y1 -> Y2 & 0.440 & 0.417 & 0.173 & 2.545 & 0.006 \\
\hline
\end{tabular}

\section{Effect of Brand Image (X1) on Customer Satisfaction (Y1)}

Based on the results of the analysis using smartPLS, it can be concluded that the Brand Image construct has a significant effect on the construct of Customer Satisfaction. This can be seen from the $t$ value of 7.229. This value is greater than $\mathrm{t}$ table $(1,960)$. Thus, the $\mathrm{H} 1$ hypothesis in this study was accepted. This shows that a good Brand Image will cause customers to be satisfied with the Ara Shop.

This is also supported by research conducted by Mujahidin et al., 2018 which shows that Brand Image has a significant effect on customer satisfaction.

\section{Effect of Brand Image (X1) on Customer Loyalty (Y2)}

Based on the results of the analysis using smartPLS, it can be concluded that the Brand Image construct has a significant effect on the construct of Customer Loyalty. This can be seen from the t value of 2.261. This value is greater than $\mathrm{t}$ table $(1,960)$. Thus, the $\mathrm{H} 2$ hypothesis in this study was accepted. This shows that a good Brand Image will encourage customers to make regular purchases at Ara Shop.

This is contrary to the research conducted by Kesetiaan et al., (2017). It is known that Brand Image has no effect on Customer Satisfaction.

\section{Effect of Brand Trust (X2) on Customer Loyalty (Y2)}

Based on the results of the analysis using smartPLS, it can be concluded that the construct of Brand Trust has a significant effect on the construct of Customer Loyalty. This can be seen from $t$ at 2,133 . This value is greater than $t$ table $(1,960)$. Thus, the H5 hypothesis in this study was accepted. This shows that a good Brand Trust will encourage customers to make regular purchases at Ara Shop.

This is in contrast to the research conducted by Kolonio and Soepeno (2019). It is known that partially brand trust does not have a significant effect on consumer loyalty..

\section{Effect of Customer Satisfaction (Y1) on Customer Loyalty (Y2)}

Based on the results of the analysis using smartPLS, it can be concluded that the construct of customer satisfaction has a significant effect on the construct of Customer Loyalty. This can be seen from $t$ of 2,545. This value is greater than $\mathrm{t}$ table $(1,960)$. Thus, the H5 hypothesis in this study was accepted. This shows that satisfied customers are very influential to make regular purchases at Ara Shop.

This is also supported by research conducted by Sari (2018), which shows that customer satisfaction has a direct effect on customer loyalty

\section{CONCLUSIONS AND SUGGESTIONS}

\section{Conclusion}

Based on the problems that have been formulated, the results of the analysis and testing of hypotheses that have been carried out in the previous chapter, then conclusions can be drawn from the research as follows:

1. The results of data processing indicate a significant influence between the variable Brand Image on Customer Satisfaction with a p-value of 0,000 and a t value of 7,229. Based on the results of processing the data this means that a good Brand Image will cause customers to be satisfied with the Ara Shop.

2. The results of data processing indicate a significant influence between Brand Image variables on customer loyalty with a p-value of 0.012 and a $t$ value of 2.261. Based on the results of processing the data this means that a good Brand Image will encourage consumers to make regular purchases at the Ara Shop. 
3. The results of data processing indicate a significant influence between the Brand Trust variable on Customer Satisfaction with a p-value of 0.025 and a t value of 1.963. Based on the results of processing the data this means that a good Brand Trust will cause customers to be satisfied with the Ara Shop.

4. The results of data processing indicate a significant influence between the Brand Trust variable on Customer Loyalty with a p-value of 0.017 and a $t$ value of 2.133. Based on the results of data processing, this means that a good Brand Trust will encourage customers to make regular purchases at Ara Shop

5. The results of data processing indicate a significant influence between Customer Satisfaction variables on Customer Loyalty with a p-value of 0.006 and a $t$ value of 2.545. Based on the results of data processing, this means that satisfied customers will be compelled to make regular purchases at the Ara Shop.

\section{Suggestion}

To further enhance customer satisfaction and loyalty, the authors provide the following suggestions:

1. Brand Image is a very important thing to be considered by business people especially in the field of beauty because a good brand image will encourage consumers to be interested in buying, which will then make consumers feel satisfied. in general if consumers feel satisfied they will tell others about the good things they have felt. In testing this researcher, the brand image is considered to be satisfactory. Because it can be seen from its significant value in the Path coefficient test, so shop owners give at least a slight increase in terms of adding shopping facilities such as various e-commerce.

2. Trust brands are no less important to be noticed by business people especially in the field of beauty because good brand trust will make consumers feel safe and comfortable when using products or services offered so that consumers make purchases regularly. Brand trust in this test can also be said to be satisfactory. Because it can be seen from its significant value in the Path coefficient test, so for shop owners it is enough to improve shipping in order to serve quickly and precisely customer orders so that there are no late delivery of orders because late delivery of orders will affect customer satisfaction and loyalty to make purchases reset it.

3. For the next researcher, it is expected to be able to develop further research with the same topic, but rather consider other or different variables that can provide solutions in the relationship between customer satisfaction and loyalty.

\section{REFERENCE}

Hurriyati, Ratih. (2008). Marketing Mix and Consumer Loyalty. Bandung: Alfabeta.

Ika, N \& Kustini. (2011). Experiential Marketing, Emotional Branding, and Brand Trust and Their Effect on Loyalty on Honda Motorcycle Products. Journal of Venture Economics, Business and Accountancy. Vol. 14, No. 1. P 19-28. Veteran National Development University, Surabaya.

Joseph F. Hair. 2014. "PLS-SEM: Indeed a Silver Bullet." PLS-SEM: Indeed a Silver Bullet (January 2015): 3741.

Loyalty, T. Et Al. (2017) "ISSN 2303-1174 A.M. Tumewu. , S.Pangemanan., F.Tumewu. The Effect Of Customer Trust, ......" (2), p. 552-563.

Kolonio, J. And Soepeno, D. (2019) "Effects of Service Quality, Trust, and Consumer Satisfaction on Consumer Loyalty at Cv. Facilities of Marine Fiberglass Effect of Service Quality, Trust, and Consumer Satisfaction On Consumer Loyalty On Cv. Marine Fiberglass Facilities, "7 (1), p. 831-840.

Kotler, Philip. 2007. Marketing Management Volume I (Indonesian Edition) Jakarta: PT. Index

Lau, Geok Then And Sook Han Lee, "Custaomer's Trust In A Brand And The Link To Loyalty", Journal Of Market Focussed Management, 1999

Mujahideen, A. Et Al. (2018) "The Effect of Higher Education Image and Lecturer Competence on Student Loyalty Through Student Satisfaction in Private Universities (Study at IKIP PGRI Bojonegoro)," 4 (2), p. 49-66.

S. Ghozali, M.Com, Ph.D, Ak Laten, Partial Least Squares. 2015

Sari, N. (2018) "The International Journal Of Social Sciences Service Quality, Company Image, Trust And Its Influence On Customers' At Bank Shariah Mandiri Satisfaction And Loyalty (BSM)

Sugiyono. 2013. "Quantitative, Qualitative and R \& D Research Methods (251):215

Zeithaml, V., Bitner, M.J., and Gremeler, D.D ,. (2009). Service Marketing - integrating the 5th Edition customer focus across the firm. McGraw-Hill: New York Kertajaya, 